\title{
Correlation between first trimester uric acid level and subsequent development of gestational diabetes mellitus
}

\author{
Amudha P.*, Nithya D., Pradeeba S., Manochithra B.
}

Department of Obstetrics and Gynecology, Thanjavur Medical College, Thanjavur, Tamil nadu, India

Received: 02 December 2016

Accepted: 26 December 2016

*Correspondence:

Dr. Amudha P.,

E-mail: amudha70dr@gmail.com

Copyright: () the author(s), publisher and licensee Medip Academy. This is an open-access article distributed under the terms of the Creative Commons Attribution Non-Commercial License, which permits unrestricted non-commercial use, distribution, and reproduction in any medium, provided the original work is properly cited.

\begin{abstract}
Background: The aim of the study was to correlate between first trimester uric acid level and its association with subsequent development of gestational diabetes mellitus.

Methods: This is a prospective study conducted at Govt. Raja Mirasudar Hospital attached to Thanjavur Medical College, Thanjavur over a period of one year from September 2015. A total of one hundred and eighty seven ante natal women less than 14 weeks of gestational age who attended the outpatient antenatal department were included in this study. Serum uric acid estimation was done in women with $<14$ weeks of gestation and they were subsequently screened for GDM between 24 to 28 weeks by oral glucose tolerance test (OGTT) with 75 gms glucose according to IADPSG criteria.

Results: In our study, among 178 antenatal pregnant women 13 with uric acid $>3.6 \mathrm{mg} / \mathrm{dl}$ and 2 with serum uric acid $<3.6 \mathrm{mg} / \mathrm{dl}$ developed GDM. This shows development of GDM increases with increase in uric acid concentration.

Conclusions: Though our study results suggest that serum uric acid level estimation in first trimester can be used as a marker to predict GDM in pregnant women, large scale studies are required before it can be recommended as a routine first trimester screening test for prediction of gestational diabetes mellitus.
\end{abstract}

Keywords: GDM, Uric acid

\section{INTRODUCTION}

Gestational diabetes mellitus (GDM) is one of the most challenging medical complications encountered during pregnancy. WHO and the American diabetic association defines GDM as 'any degree of glucose intolerance with onset or first recognition during pregnancy". ${ }^{1}$ GDM has gained utmost importance nowadays because, half of GDM women ultimately develop type 2 diabetes mellitus (T 2DM) in the ensuing 20 years. In-utero exposure to hyperglycemia can lead to childhood obesity and diabetes.

Prevalence of GDM ranges from 1 to $14 \% .^{2}$ The fact that Asians are at high risk for development of GDM necessitates early diagnosis. There continues to be several controversies regarding screening and treatment of GDM.
Early diagnosis of GDM using OGTT is done between 24 and 28 weeks of gestational age. But no tests are available before this gestational age, which can predict the development of GDM. In developing countries like ours, early detection and prevention of associated morbidity will be more cost effective.

Serum uric acid is associated with insulin resistance and several mechanisms have been hypothesized to explain this association. Nakagawa et al (2007) state that uric acid causes endothelial dysfunction and decreases nitric oxide production. ${ }^{3}$ In animals, insulin mediated glucose uptake into cells in the skeletal muscles and adipose tissue is dependent on nitric oxide. Thus, decrease in nitric oxide leads to decreased glucose uptake and development of insulin resistance. ${ }^{4}$ Another mechanism is that, uric acid may induce insulin resistance and cause 
inflammation and oxidative stress in adipocytes, which is a contributor to the development of metabolic syndrome. ${ }^{5}$ Normally during pregnancy, the serum uric acid level decreases significantly between 8 and 24 weeks of gestation due to increased glomerular filtration rate and reduced re-absorption of uric acid from renal tubules. In first trimester, it likely approximates preconception uric acid levels, and elevated levels may identify women who are predisposed to metabolic syndrome with an increased risk of developing GDM. ${ }^{6}$ This concept would be useful in predicting GDM at an earlier gestational age, there by aiding in initiating timely and appropriate management to prevent maternal and fetal morbidity and mortality.

\section{METHODS}

This is a prospective study conducted at Govt. Raja Mirasudar Hospital attached to Thanjavur Medical College, Thanjavur over a period of one year from September 2015. The sample size was ascertained after a power calculation by a statistician. A total of one hundred and eighty seven antenatal women less than 14 weeks of gestational age who attended the outpatient antenatal department were included in this study.

\section{Inclusion criteria}

Antenatal women with gestational age $<14$ weeks and whose fasting blood sugar was $<92 \mathrm{mg} / \mathrm{dl}$ were included in the study.

\section{Exclusion criteria}

Women with

- $\quad$ Pre GDM
- GDM

- Renal disease

- Tuberculosis

- Bronchial asthma

- Liver diseases

- Cardiovascular diseases

- Gout

- Connective tissue disorder

- Chronic hypertension and women on drugs causing hyperuricemia were excluded from the study.

\section{Procedure of the study}

Antenatal women $<14$ wks of gestation $\rightarrow$ Fasting blood sugar estimation done. FBS $>126 \mathrm{mg} / \mathrm{dl} \rightarrow$ labelled as Overt DM \& FBS 92-125 mg/dl labelled as GDM $\rightarrow$ were excluded from the study. FBS $<92 \mathrm{mg} / \mathrm{dl}$ were included in this study $\rightarrow$ serum uric acid estimation done--patients were followed up around 24 to 28 weeks $\rightarrow$ GDM screening done with OGTT(75 gms of glucose) as per IADPSG criteria.

The collected data was statistically analyzed using Chisquare test, ANOVA test, student t test. A receiver operator curve analysis was done to decide on a cut off for serum uric acid levels, which would serve as a marker to predict subsequent development of GDM.

\section{RESULTS}

One hundred and eighty seven pregnant women were enrolled in the study. Of these, 9 were lost to follow-up. The mean age of the sample was 23.6 years $(\mathrm{SD}=3.3)$. The majority were primigravidae $(64.6 \%)$. The majority $(93.3 \%)$ had a BMI between 18.5and 24.9, with the mean BMI being $21.9(\mathrm{SD}=2.09)$.

Table 1: Serum uric acid levels and development of GDM in different age groups.

\begin{tabular}{|lllll|}
\hline \multirow{2}{*}{ Age (in years) } & Uric acid concentration (mg/dl) & OGTT status & SI \\
& Range & Normal & Abnormal (GDM) & $\mathrm{X}^{2}=11.409$ \\
\hline$\leq 20$ & $1.6-4.2$ & 30 & 6 & Df $=3$ \\
\hline $21-25$ & $1.7-4.0$ & 93 & 2 & P $<0.05$ \\
\hline $26-30$ & $1.8-4.2$ & 33 & 5 & Significant \\
\hline$>30$ & $1.9-4.1$ & 7 & 2 & \\
\hline
\end{tabular}

Table 2: Correlation of serum uric acid level with OGTT status.

\begin{tabular}{|llll|}
\hline Serum uric acid concentration $(\mathbf{m g} / \mathrm{dl})$ & OGTT Status & Abnormal(GDM) \\
\hline $1.0-2.0$ & No. of subjects & Normal & 0 \\
\hline $2.1-3.0$ & 32 & 32 & 2 \\
\hline $3.1-4.0$ & 121 & 119 & 5 \\
\hline$>4.0$ & 17 & 12 & 8 \\
\hline
\end{tabular}


Fifteen out of one hundred and seventy eight women developed gestational diabetic mellitus on follow up. Table 1 shows that the mean serum uric acid level increases with age, and this was found to be statistically significant $(\mathrm{P}$ value $<0.001)$. The results also showed that a significantly higher proportion of older women developed GDM compared to younger women, and this also was found to be statistically significant $(\mathrm{p}<0.05)$.

There was no association between parity and the serum uric acid level at less than 14 weeks of pregnancy $(\mathrm{P}=0.538)$. Primigravidae constituted $64.6 \%$ of the total study sample, out of which $7.82 \%$ developed GDM $(\mathrm{P}=0.417)$. Area under the curve 0.914; Standard error0.051 . A cut off serum uric acid level of $3.6 \mathrm{mg} / \mathrm{dl}$ was found to have $92 \%$ sensitivity; specificity of $99 \%$ for the development of GDM.

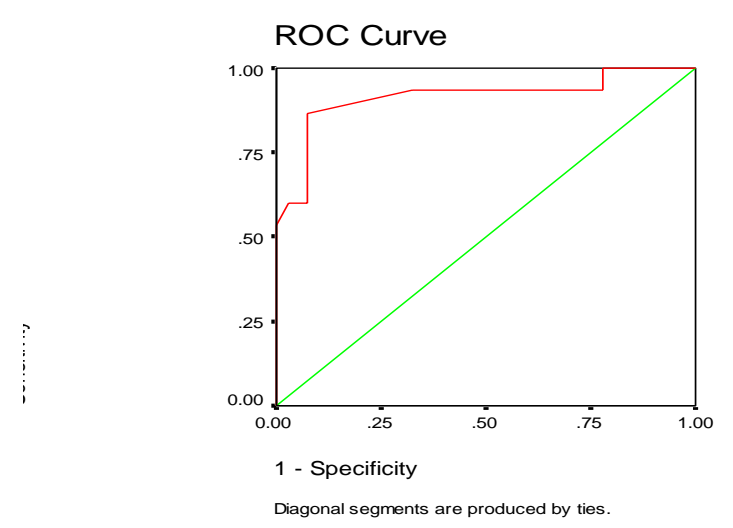

Figure 1: ROC curve for serum uric acid in relation to an outcome of GDM.

Table 3: Distribution of cases in relation to serum uric acid.

\begin{tabular}{|lllll|}
\hline Sr uric acid(mg/dl) & Frequency & Percent & Valid Percent & Cumulative Percent \\
\hline Less than 3.6 & 153 & 86.0 & 86.0 & 86.0 \\
\hline More Than 3.6 & 25 & 14.0 & 14.0 & 100.0 \\
\hline Total & 178 & 100.0 & 100.0 & \\
\hline
\end{tabular}

Table 4: Distribution GDM using serum uric acid cut off $3.6 \mathrm{mg} / \mathrm{dl}$.

\begin{tabular}{|llll|}
\hline $\begin{array}{l}\text { Uric acid } \\
(\mathbf{m g} / \mathbf{d l})\end{array}$ & GDM & Non GDM & Total \\
\hline$<3.6$ & 2 & 151 & 153 \\
\hline$>3.6$ & 13 & 12 & 25 \\
\hline Total & 15 & 163 & 178 \\
\hline
\end{tabular}

There was no significant association between BMI and serum uric acid levels in our study $(\mathrm{p}=0.194)$.

Table 5: Distribution of risk factors with development of GDM.

\begin{tabular}{|llllll|}
\hline $\begin{array}{l}\text { Uric } \\
\text { acid } \\
\text { (mg/dl) }\end{array}$ & $\begin{array}{l}\text { Number } \\
\text { of } \\
\text { women }\end{array}$ & $\begin{array}{l}\text { Risk } \\
\text { factors }\end{array}$ & $\begin{array}{l}\text { No } \\
\text { risk } \\
\text { factors }\end{array}$ & $\begin{array}{l}\text { GDM } \\
\text { RF }\end{array}$ & $\begin{array}{l}\text { Without } \\
\text { RF }\end{array}$ \\
\hline$<3.6$ & 153 & 19 & 134 & 2 & 0 \\
\hline$>3.6$ & 25 & 10 & 15 & 6 & 7 \\
\hline
\end{tabular}

Similarly no correlation was observed between BMI and development of GDM in our study $(\mathrm{p}=0.277)$.

On analyzing the data to explore the association of serum uric acid levels with development of GDM (Table 2), significantly higher proportion of women with higher serum uric acid levels developed GDM compared to those with lower serum uric acid levels $(P<0.01)$. Finally, a receiver operator curve analysis was done to ascertain a suitable serum uric acid cut off, so as to suggest as a marker for subsequent development of GDM (Figure 1).

In our study $86 \%$ of women had serum uric acid $<3.6 \mathrm{mg} / \mathrm{dl}$ and $14 \%$ of them had serum uric acid $>3.6 \mathrm{mg} / \mathrm{dl}$ (Table 3$)$.

Among the 178 women, 13 with uric acid $>3.6 \mathrm{mg} / \mathrm{dl}$ and 2 with serum uric acid $<3.6 \mathrm{mg} / \mathrm{dl}$ developed GDM. This shows increased serum uric acid concentration was associated with statistically higher incidence of development of GDM $(\mathrm{P}<0.01)$ (Table 4$)$.

\section{Risk factors and GDM}

On performing risk factor stratification, a higher incidence of GDM was observed in women with family history of DM and in those with previous history of GDM. Out of 153 women with serum uric acid level less than $3.6 \mathrm{mg} / \mathrm{dl}, 19$ women had risk factors, of which 2 developed GDM. Out of 25 women with serum uric acid level more than $3.6 \mathrm{mg} / \mathrm{dl}$, 6 out of 10 women with risk factors and 7 out of 15 women with no risk factors developed GDM (Table 5).

\section{DISCUSSION}

Early intervention and appropriate management in women with GDM or in those with increased risk for developing GDM will be helpful in preventing the adverse maternal and perinatal outcome and also protect 
them from long term consequences. The purpose of screening for and management of GDM is to prevent stillbirths, congenital anomalies, recurrent abortion, preeclampsia, intrauterine death and to decrease the incidence of macrosomic babies, thereby reducing maternal and perinatal morbidity and mortality. Several studies have shown the association of hyperuricaemia in the first trimester with development of gestational diabetes mellitus later in life.

In present study, amongst the background variables analyzed, age seemed to be significantly associated with increase in serum uric acid level and development of GDM $(\mathrm{P}<0.05)$. This finding is consistent with previous studies that have reported increasing incidence of GDM and high serum uric acid levels with increasing age. ${ }^{8,9}$

Out of 178 women studied, 64.6\% were primigravidae and $45.4 \%$ were multigravidae. In our study, there was no significant difference in serum uric acid levels between primigravidae and multigravidae at $<14$ weeks of pregnancy $(\mathrm{P}=0.538)$.The same finding has been observed by Dunlop W et al in their study on effect of renal handling of uric acid in pregnancy.${ }^{10}$ On the contrary, Aparna K et al has reported significantly higher mean uric acid levels in multiparous women. ${ }^{11}$ In our study, we found no difference in the incidence of development of GDM in relation to parity $(\mathrm{P}=0.417)$ which was consistent with the results of Aparna $\mathrm{K}$ et al. ${ }^{11}$ Nagalakshmi C et al had observed a higher incidence of GDM among primigravidae, while Al Rowally et al. had observed the same in multiparous women. ${ }^{12,13}$

On analyzing the correlation between BMI and serum uric acid levels we noted that, though there was some proportional increase in serum uric acid levels with increase in BMI, it was not statistically significant in our study $(p=0.194)$. We also found that, BMI is not statistically associated with GDM development $(\mathrm{P}=0.217)$.This was in agreement with the results of several authors who reported that the association between elevated uric acid at early trimester and risk of development of GDM was independent of BMI. ${ }^{6,11}$

On risk factor stratification, there was significant correlation between family history of diabetes and development of GDM in second trimester $(\mathrm{P}<0.05 \%)$. This finding of ours was consistent with that of Ratnakaran R et al. ${ }^{14}$

In our study, there was a moderately significant correlation $(p=0.048)$ between previous history of GDM and recurrent GDM in present pregnancy, which was also observed by Sindhuja A et al. ${ }^{15}$

Other risk factors like bad obstetric history, polycystic ovarian disease, and previous history of macrosomia were not significantly associated with development of GDM in our study. On the contrary, Toulis et al found PCOD to be the main risk factor for development of GDM. ${ }^{16}$
The results from present study suggest that increased serum uric acid in early trimester was associated with higher incidence of GDM. This finding is in accordance with that of Laughon et al and Aparna $\mathrm{K}$ et al who also found a dose related increase in risk of development of GDM with increase in serum uric acid levels and also suggested that elevated serum uric acid could serve as a marker for subsequent development of GDM.6,11 Hyperuricemia also has been suggested as a marker for later development of metabolic syndrome and type $2 \mathrm{DM}$.

To explore this further, we conducted a receiver operator characteristic analysis to ascertain appropriate cut- off for serum uric acid level that might best predict GDM development. None of our patients were actually hyperuricemic (defined as serum uric acid $>6 \mathrm{mg} / \mathrm{dl}$ ). This notwithstanding, rise in serum uric acid levels were still associated with a higher risk of development of GDM in our study. A cut-off of $3.6 \mathrm{mg} / \mathrm{dl}$ seemed to achieve a good balance of sensitivity (92\%) and specificity (99\%) in our study. Laughon et al found that serum uric acid levels of more than $3.6 \mathrm{mg} / \mathrm{dl}$ in early gestation is associated with a threefold increased risk of development of GDM. ${ }^{6}$ Aparna $\mathrm{K}$ et al was also found that serum uric acid $>3.4 \mathrm{mg}$ in first trimester is associated with GDM Occurrence.

In our study, there was a highly significant correlation between serum uric acid at $<14$ weeks of gestation and development of GDM (Pearson correlation).This is due to the fact that serum uric acid levels normally fall in the early trimester and mid trimester and rises to non pregnant values in late pregnancy. Elevated or high normal levels of serum uric acid in first trimester may be associated with a pre existing metabolic derangements which lead to poor maternal physiological adaptations and predisposes the pregnant women to development of pregnancy complication like gestational diabetes mellitus.

The potential limitation of our study was that, the study subjects were not followed up after 28 wks of gestation and hence fetomaternal outcomes were not analysed.

\section{CONCLUSION}

The complications of gestational diabetes mellitus in pregnancy are often diagnosed only after mid-late gestation. By the time the diagnosis of gestational diabetes mellitus is made, the potential adverse perinatal outcome may become irreversible. Hence, it becomes mandatory to do the diagnostic/predictive tests to diagnose the gestational diabetes mellitus at the earliest. Even though risk factors like obesity, previous history of GDM, family history of Type 2 DM, PCOD, previous history of macrosomia, bad obstetric history are associated with the development of GDM, our study showed that, pregnant women without these risk factors also developed GDM when the serum uric acid level is more than $3.6 \mathrm{mg} / \mathrm{dl}$. Though our study results suggest that serum uric acid level estimation in first trimester can 
be used as a marker to predict GDM in pregnant women, larger studies are required before it can be recommended as a routine first trimester screening test for prediction of GDM, so that its dreadful complications can be avoided in future.

Funding: No funding sources

Conflict of interest: None declared

Ethical approval: The study was approved by the Institutional Ethics Committee of Thanjavur Medical College, Thanjavur

\section{REFERENCES}

1. The American College of obstetricians and gynaecologists practice bulletin. 2013;122:406-16.

2. Persson B, Hanson U. Neonatal morbidities in gestational diabetes mellitus. Diabetes care. 1998;21:B79.

3. Nakagawa T. Uncoupling of the VEGF-endothelial nitric oxide axis in diabetic nephropathy: an explanation for the paradoxical effects of VEGF in renal disease. Am J Physiol Renal Physiol. 2007;292:F1665-72.

4. Cooke JP. NO and Angiogenesis. Atheroscler suppl. 2003;4(4):53-60.

5. Furukawa S, Fujita T, Shimabukuro M, Iwaki M, Yamada Y, Nakajima YM, et al. Increased oxidative stress in obesity and its impact on metabolic syndrome. The Journal of clinical investigation. 2004;114(12):1752-61.

6. Laughon SK, Catovr J. Elevated first-trimester uric acid concentrations are associated with the development of gestational diabetes. Am J Obstet Gynecol. 2009;201:402.e1-5.

7. International Association of Diabetes and Pregnancy study group consensus panel. Diabetes care. 2010;33(3).

8. Carolan M, Davey MA, Biro MA, Kealy M. Maternal age, ethnicity and gestational diabetes mellitus. Midwifery. 2012;28(6):778-83.
9. Qiu L, Cheng XQ, Wu J, Liu JT, Xu T, Ding HT, et al. Prevalence of hyperuricemia and its related risk factors in healthy adults from Northern and Northeastern Chinese provinces. BMC Public Health. 2013;13(1):1.

10. Dunlop W, Davison, JM. The effect of normal pregnancy upon the renal handling of uric acid. An International Journal of Obstetrics Gynaecology. 1977;84:13-21.

11. Aparna K. Increased uric acid and GDM occurrence. International Journal of Dental and Medical Science. 2013;13.

12. Nagalakshmi CS, Devaki RN, Akila P, Suma KB. Exploration of the clinico-biochemical parameters to explain the altered renal mechanisms in gestational diabetes mellitus. Journal of Clinical and Diagnostic Research. 2012;6:369-71.

13. Al-Rowaily MA, Abolfotouh MA. Predictors of gestational diabetes mellitus in a high-parity community in Saudi Arabia. East Mediterr Health J. 2010;16(6):636-41.

14. Retnakaran R, Connelly PW, Sermer M, Zinman B, Hanley AJ. The impact of family history of diabetes on risk factors for gestational diabetes. Clinical endocrinology. 2007;67(5):754-60.

15. Sindhujha A. Correlation between first trimester uric acid level and its association with gestational diabetes mellitus. International Journal of Modern Research and Reviews. 2014;2(9):295-7.

16. Toulis KA, Goulis DG, Kolibianakis EM, Venetis CA, Tarlatzis BC, Papadimas I. Risk of gestational diabetes mellitus in women with polycystic ovary syndrome: a systematic review and a meta-analysis. Fertility and sterility. 2009;92(2):667-77.

Cite this article as: Amudha $\mathrm{P}$, Nithya D, Pradeeba S, Manochithra B. Correlation between first trimester uric acid level and subsequent development of gestational diabetes mellitus. Int J Reprod Contracept Obstet Gynecol 2017;6:606-10. 